\title{
Learning Styles and Strategies of Teaching the Filipino Language
}

\author{
Jessalyn Marie L. Englis \\ Palompon Institute of Technology, Palompon, Leyte
}

\begin{abstract}
The success of learning a certain language that uses appropriate style helps in the enhancement of the performance of the learners. The main objective of this study is to identify the learning styles of the students in the first level of tertiary education of Filipino language and determine the strategies and techniques, the teachers use in teaching Filipino subject at Palompon Institute of Technology - Tabango Campus. Using descriptive design, the learning styles of the students and the strategies used by the teachers in teaching Filipino were identified and determined. The researchers also examined if the learning styles and the teaching strategies have a significant correlation towards learning the Filipino language. It came out that most of the learners are visual learners while the teachers appeal to the bodily kinesthetic aspect of the students. Thus, the learning style of the learners and the strategies used by the teachers have no significant relationship in the students' learning. With this, it is recommended that the developed enhancement program must be implemented to help link the learners' learning styles towards excellent language learning.
\end{abstract}

Keywords - Learning Styles, Teaching Strategies, Second Language, Descriptive, Palompon Institute of Technology - Tabango Campus

\section{INTRODUCTION}

The Philippines is an archipelago that has numerous dialects used in communicating particular to the province they belong. Moreover, many foreigners have colonized the nation that brought and introduced languages that were used by the Filipinos. In fact, there are a total of one hundred fifty (150) languages that are still active up to this day. Some of the dialects being used in the regions, Visayas and Mindanao, are Cebuano, Hiligaynon, Waray - waray, Tausug, Bikolano, and Illonggo while majority of those in Luzon uses Tagalog.

There are times that Filipinos do not understand each other due to the variety of language being used. Though happened to be in just one particular place, several dialects can be observed.

The importance of Filipino Language, given emphasis by Manuel L. Quezon, is considered as the national language of the Philippines. It represents and symbolizes the unity of the Filipinos. Lachica (1996) posits that art is very important in a person's life because through this, he can communicate and express his feelings. Through this, everyone can express his insights, thoughts, ideas and opinions about the events happening in the country.

Language is an art that embodies the people's beliefs, customs and traditions. This is an inheritance from our ancestors that gives a wide range of knowledge to the students to know and understand the usage of a certain language, supplementing to the efforts they have invested to know more about it.

The success of learning a certain language that uses appropriate style helps in the enhancement of the performance of the learners. The learners use styles appropriate to the level of their intelligence, personality, age and objective to know the language. The teachers are the persons responsible for encouraging students to use good and appropriate styles while it is the internal responsibility of the students to encourage themselves to achieve more enhanced usage of their learning styles.

The importance of the learning styles and teaching strategies towards excellent usage of the second language paved the way for the researchers to give careful and meticulous study of the learning styles being used by the learners during their first year in college as well as the teaching strategies of the teachers at Palompon Institute of Technology - Tabango Campus to come up with a solution that is vital in learning a language which could also be taught to the students, taking Filipino courses as well as the language teachers.

Theoretical/Conceptual Framework

This study is based on Kolb's (1984) model about learning styles where it was most known and used theory. He believes that the learning of an individual in language can be seen through their experiences in life and the demands of their present environment. He developed experiential theory showing that learning is a four (4) stage cycle. First, the direct experience is the basis for observation. The reflection of the individual through observation comes next, where the forming of theories about the meaning of the information takes place. In the next 
stage, the learners will create an abstract concept and evaluation basing on the hypothesis they have made. Finally, the learners will apply the implications about the formed concept to new situations and events.

These theories are being supported by the different language theories in learning that was introduced to describe as to how it would be achieved through the use of appropriate learning styles.

The main theory is the theory of behaviorism by J. B. Watson, which is originally from psychological theory. This is about the behavioural analysis of a person in the observable stimulus - response through interaction. According to the behaviourists' belief in language learning, children uses styles to learn through imitation.

According to Bloomfield (1993) learning a language could be attained through constant practice. The language learning process has something to do with learning other disciplines. This theory was from the idea of the relationship of stimulus and response. Behaviourists observed that the learners have exposed to many stimuli from the environment and from the very context they are in. The behaviour is formed because of their response to the present stimuli through repeated reinforcement. Another theory is the interactionism. According to Krashen (1982), every individual has an innate mechanism to learn a language with comprehensive input. The language develops and results to forming interaction among the children and the speaker of the language. Every student should interact and communicate to others to apply what they have learned and show their knowledge and skills. Thus, the learners will develop their abilities in the language if they have the competence in communicating instead of repeated practice. (Nunen 1991).

\section{Significance of the Study}

The main objective of this study is to determine the different learning styles used by the learners in the first year of their tertiary education in learning Filipino language and the strategies and techniques used by the teachers in teaching Filipino subject during the academic year 2013 - 2014.

The performance of the learners in Filipino subject was determined in accordance with their grades for the whole semester and with the styles they used in learning the language whether they are visual, auditory, kinesthetic, or unique individual style.

On the other hand, the teaching strategies and techniques used by the teachers in teaching Filipino language were also determined to see if there had been a meaningful connection to the learning styles used by the learners in learning the language.

Finally, the outcome of this study was the basis in implementing the enhancement program that could be beneficial to both the students and the language teachers.

\section{Research Instruments and Methodology}

The researchers used descriptive design to identify and determine the styles used by the learners in language learning and the strategies and techniques used by the teachers in teaching the language. This study used questionnaires in collecting the necessary data. The questionnaires were composed to identify the performance of the students in learning the language. The items in the questionnaires, moreover, helped the researchers in determining the styles used by the students in learning the language as well as the teaching strategies used by the language teachers.

This study was conducted at Palompon Institute of Technology - Tabango Campus (PIT - TC), an external campus of Palompon Institute of Technology (PIT), Palompon, Leyte. It offers eight (8) programs where Filipino subject is a course that needs to be taken up in all levels. In other words, all the students are required to take the subject regardless of the program they are taking.

The respondents of this study were all freshmen students in college and the language teachers of Palompon Institute of Technology - Tabango Campus. These students were currently enrolled in Filipino subject during the research survey. There were more than two hundred (200) students in the first year who were taking Filipino subject. Only fifty - five (55) students participated in the study which is the thirty percent (30\%) of the total freshmen taking Filipino subject. This research utilized the Systematic sampling technique in choosing the respondents for this study.

The questionnaires were made in accordance to the objectives to specifically identify and determine the learning styles of the students and the teaching strategies that were used by the language teachers to address the needs of the students when it comes to language learning. The data collected were analyzed and interpreted to obtain the main purpose of this study. The design of this study was simplified so that the respondents would easily understand it and would not find any difficulty in answering the identified questions. The first part of this study entails the performance of the students in the Filipino subject, and the second part is about the different teaching strategies employed by the language teachers. This was made to determine the correlation of the identified learning 
styles of the students to the teaching strategies used by the language teachers. The last part entails the Enhancement Program to further develop the practice of students' learning and the teaching procedures of the language teachers teaching Filipino subjects.

The effectivity of the instruments used in the study was not significant to the given learning styles and teaching strategies since it is from the standardized test made by Selime Tabanlioglu. The researchers translated all the questions used related to the study. On the other hand, the instruments used in identifying and determining the learning styles and teaching strategies were taken from Eman Aljan Alshehri (n.d.).

The statistical analysis used in this research is the Pearson $\mathrm{R}$ to find out if there had been a positive correlation between the learning styles of the students in learning the language and the strategies used by the language teachers. The $\mathrm{T}$ - test is to distinguish if there had been a difference in the learning styles used by the students from the strategies used by the teachers.

\section{Results and Discussions}

\section{Students' Performance in Filipino Language}

The grades of the students in the Filipino subject is mostly in 1.5 up to 2.4 which proves that the students have good grades in the subject. The interest they infused was according to their extensive knowledge in learning it. Their focus and attention towards listening and participating in the activities and tasks given by the teacher is a manifestation of the abilities they possess. All the activities provided by the teacher was appropriate to the students' abilities and level of understanding. The learners were divided into three levels of knowledge and proficiency that is why the grades they obtained was correspondent to their performance as to how they comprehended and get the concept in each lesson. The results were validated through the gathered data of the researchers, showing that each participant of the study is in the average level in terms of learning Filipino language.

\begin{tabular}{lcc} 
& $\begin{array}{c}\text { Student Learning Styles in Filipino } \\
\text { Table 1. Learning Styles of Filipino }\end{array}$ & \\
\hline Learning Styles Mean & Interpretation & Moderately True \\
\hline Visual & 3.28 & Moderately True \\
Auditory & 3.18 & \\
Kinesthetic3.12 & Moderately True & \\
Tactile2.06 & Moderately True & Moderately True \\
Individual & 3.16 & \\
Weighted Mean3.17 & Moderately True & \\
\hline
\end{tabular}

Table 1 shows that different learning styles of the students in Filipino. As shown in the table, the Visual Learning Style obtained the highest mean, 3.28, which means that the students will learn better if the teacher will utilize learning materials that can be seen or read by them (visual aids). Table 7 shows that the students become intested in learning Filipino language if assisted and supported by their parents, peers, classmates and teachers, considering that Filipino language has similar structure and sound with the mother tongue. The language can be best learned when used every day.

\section{The Strategies of the Filipino Language Teachers}

Table 2 shows the different strategies used by the teachers in teaching Filipino language. It appears that the language teachers usually use varied strategies that befits to visual, auditory, kinesthetic, tactile, and individual strategies. All of these strategies and techniques promotes progressive, advanced and extensive excellence in teaching Filipino language.

Table 2

Testing the Different Learning Strategy in Filipino

\begin{tabular}{lcc}
\hline Teaching StrategyMean & Interpretation & \\
\hline Visual & 3.50 & Usually true description \\
Auditory & 3.40 & Usually true description \\
Kinesthetic & 3.71 & Usually true description \\
Tactile & 3.43 & Usually true description \\
Individual & 3.56 & Usually true description \\
Weighted Mean & $\mathbf{3 . 5 2}$ & Usually true description \\
\hline
\end{tabular}




\section{Correlation of Learning Styles and Teaching Strategies}

Table 3 shows that there is a negative correlation between the learning styles of the students and the teaching strategies used by the teachers at $1 \%$ level of significance and there has been no significant correlation in the learning styles and strategies of teaching the Filipino language.

Table 3

Relationship Between Learning Styles and Learning Strategy in Filipino

\begin{tabular}{lcc}
\hline \multicolumn{1}{c}{ Computed } & P-value & Interpretation \\
\hline Significanttvalue $=3.42$ & 0.009132403 & $\begin{array}{c}\text { Significant at } 1 \% \\
\text { Difference }(\mathrm{t} \text {-test) }\end{array}$ \\
$\begin{array}{l}\text { Significant } \quad \text { Value }=0.139912 \\
\text { Correlation }\end{array}$ & 0.071 & $\begin{array}{c}\text { Level of Significance } \\
\text { (Pearson Correlation } \\
\text { Coefficient) }\end{array}$ \\
\hline
\end{tabular}

\section{Conclusion and Recommendations}

With the data gathered in this study, it was determined that the grades obtained by the students, 1.5 to 2.4 , wa based from their performance which shows that they utmost interest, proficiency and competence towards understanding the language. Among all the learning styles of the learners, learning Filipino language, the visual learning style gained the highest mean.

With regards to the teaching strategies used by the teachers in teaching Filipino language, the Kinesthetic teaching strategy prevailed with the highest mean. The results therefore show that the learning styles of the learners and the teaching strategies used by the teachers have no significant correlation. This means that there is no connection between the learning styles of the learners and the strategies used by the teachers in teaching the language.

The developed enhancement program must be implemented to ensure a positive correlation between the students' learning styles and the teachers' teaching strategies. This way, the proficiency and competence of the learners in learning the language will be enriched. The same study should be conducted by the language teachers, English or Filipino to identify the learning styles of the students that will lead to determining the appropriate teaching strategies.

\section{References}

[1] Al Asmari, A. R. (2013). Practices and Prospects of Learner Autonomy: Teachers' perceptions. English Language Teaching 6(3), 1-11.

[2] Alderman, M.K. (2007). Motivation for Achievement: Possibilities for Teaching and Learning ( $2^{\text {nd }}$ ed.) Mahwah, New Jersey: Lawrence Erlbaum Associates.

[3] Alshehri, EmanAjlan (n.d.) MOTIVATIONAL STRATEGIES: THE PERCEPTIONS OF EFL TEACHERS AND STUDENTS IN THE SAUDI HIGHER EDUCATION CONTEXT. Retrieved from http://usir.salford.ac.uk/31666/1/Final_thesis_9.pdf

[4] Ames, C., \& Archer, J. (1998). Achievement Goals in the Classroom: Students' Learning Strategies and Motivation Processes. Journal of Educational Psychology, 80(3), 260-267.

[5] Anderman, E. M., \&Anderman, L. H. (2010). Classroom Motivation. Upper Saddle River, New Jersey; Merrill.

[6] Benson, P. (2001). Teaching and Researching Autonomy in Language Learning. Essex: Pearson Educational Limited.

[7] Bloomfield (1993) Stimulus and Response. Retrieved from http://www.mohamedrabeea.com/books/book1_1532.pdf

[8] Kolb (1984) Learning Styles, Retrieved from http://www.simplypsychology.org/learning-kolb.html

[9] Tabanlioglu, Selime (n.d) The Relationship between Learning Styles and Language Learning Strategies of Pre-Intermediate EAP Students Retrieved from https://etd.lib.metu.edu.tr/upload/1014034/index.pdf

[10] Vygotsky, L. S. (1962). Thought and Language. Cambridge:MIT Press.

[11] Walberg, H. J. (1999). Productive Teaching. In H.C. Waxman \& H.J. Walberg (eds.),

[12] Watson, John B. (1913) Behaviorism Principle of Learning, Retrieved from https://principlesoflearning.wordpress.com/dissertation/chapter3-literature-review-2/the-behavioral-perpective/behaviorism-john-b-wtson-1913/

[13] New Directions for Teaching Practice Research (pp.75-104). Berkeley, California: McCutchen.

[14] Williams, M., \% Burden, R. (1999). Students' Developing Conceptions of Themselves as Language Leaners. Modern Language Journal, $83(2), 193-201$ 